\title{
Hematological Indices of Plasmodium berghei Infected Mice Treated with Ethanol Extract and Fractions of Nauclea latifolia Roots
}

\author{
E.E. Asangha ${ }^{1}$, G.O. Igile ${ }^{1 *}$, I.A. Iwara ${ }^{1}$, P.E. Ebong ${ }^{1}$ and O.A. Eseyin ${ }^{2}$ \\ ${ }^{1}$ Department of Biochemistry, Faculty of Basic Medical Sciences, University of Calabar, \\ P.M.B 1115, Calabar, Nigeria \\ ${ }^{2}$ Department of Medicinal and Pharmaceutical Chemistry, University of Uyo, \\ Akwa Ibom State, Nigeria \\ *Corresponding author
}

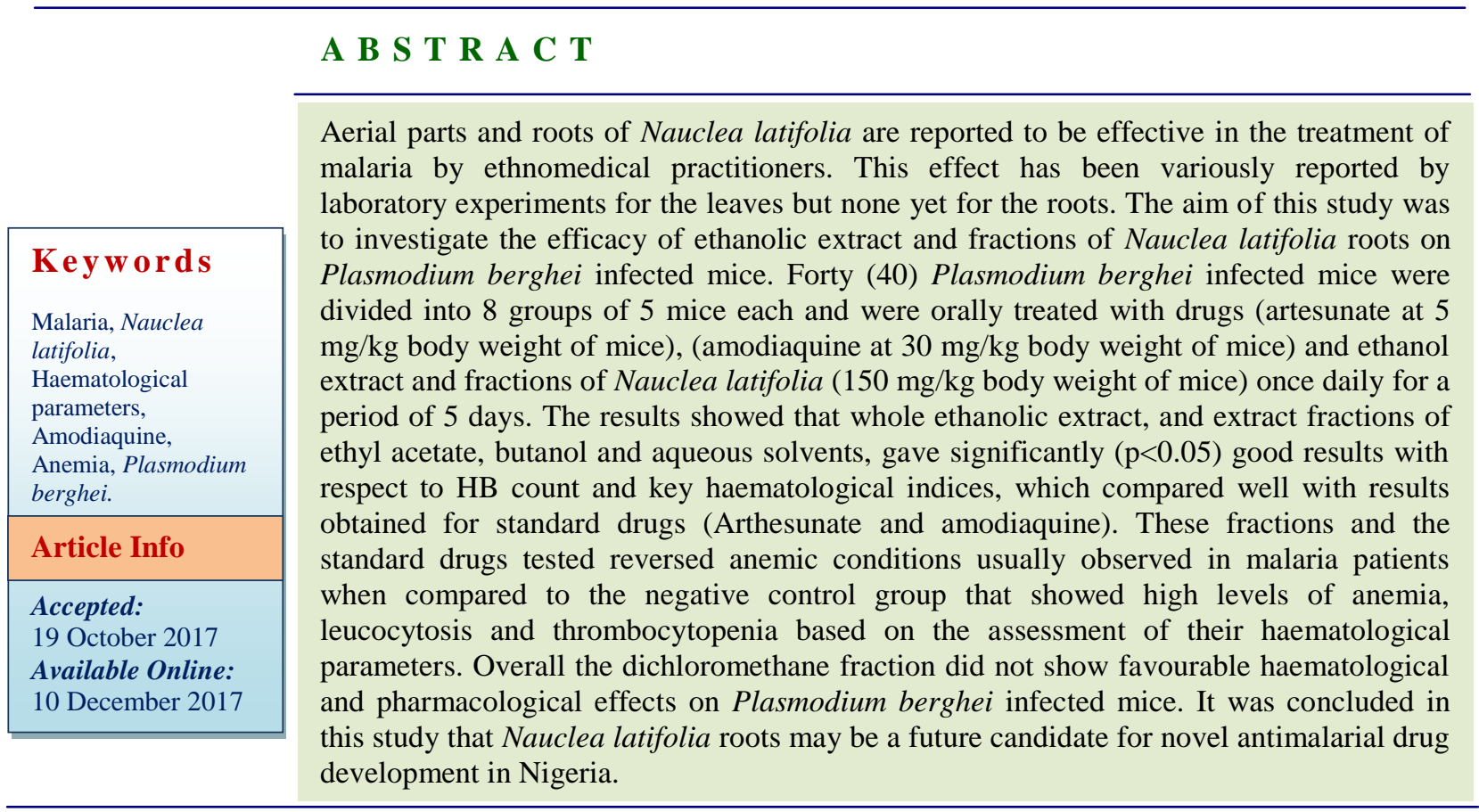

\section{Introduction}

Malaria is a parasitic disease, transmitted by the anopheles mosquito carrying the plasmodium parasites. The plasmodium species include Plasmodium falciparum, Plasmodium vivax, Plasmodium ovale, Plasmodium malariae and Plasmodium knowlesi. However, virtually all deaths from malaria are caused by Plasmodium falciparum (Smyth, 1994). Some of the symptoms/events in malaria infections are anemia, thrombocytopenia, leucocytosis, antioxidant reductions, increased lipid peroxidation, lactic acidosis, coma and death (Olayemi et al., 2012). Patients with malaria often develop haematological complications and alterations in biochemical parameters (Khan et al., 2002). The manifestations of malaria illness result from the infection of red blood cells by 
asexual forms of the malaria parasite hence, the infestation of the red blood cells make malaria a potential multi-system disease because all organs of the body depends on blood for their metabolism (Brian et al., 2008 and Fakhreldin et al., 2003). The infection of red blood cells by malaria parasites may lead to structural, biochemical and physiological modifications of the red blood cells therefore, resulting in some life-threatening symptoms of malaria. Moreover, malaria parasites attack the red blood cell thereby causing their lyses which may result in reduced haemoglobin level and packed cell volume (Okoroiwu et al., 2014). In healthy conditions, blood cells are adequately produced to a particular range based on the sex and age of the individual. The white blood cells (neutrophils, lymphocytes, eosinophils, monocytes and basophils) are the lines of defence against pathogenic invasion in animals and their percentages in differential count would give some insight on the kinds of infection an individual has. For instance, neutrophilia in bacterial infection; neutropenia in other nonbacterial related diseases; lymphocytosis in some viral and parasitic infections: basophils in blood clotting disorders; monocytes, in some bacterial infections (Okoroiwu et al., 2014). Several pathophysiological factors such as the parasite biomass; malaria toxins and inflammatory response; cytoadherence resetting and sequestration; altered deformability and fragility of parasitized erythrocytes; endothelial activation dysfunction and injury; and altered thrombostasis have been found to be involved in the development of severe malaria (Ovuakporaye, 2011).

Statistically, about $40 \%$ of the world population is at risk of the malaria disease (Snow et al., 2005). An estimated 1.2 billion is at high risk of transmission ( $\geq 1$ case per 1000 population), half of which live in the African regions; $80 \%$ of such cases are concentrated in 13 countries, and over half in Nigeria, Congo, Ethiopia, Tanzania and Kenya (WHO, 2008). However, Nigeria accounts for a quarter of all malaria cases in Africa (WHO, 2008). In the Southern part of Nigeria, transmission occurs all year round while in the North it is more seasonal. Malaria is the most common disease in Nigeria; according to the Federal Ministry of Health (2004), half of its population will have one or more malaria attacks annually.

Malaria is treatable with the use of different chemotherapeutic agents and medicinal plants over the years. The actions of most antimalarial drugs are geared towards the clearance of the parasite load in the host body system. Despite all efforts by various scientists in the prevention and treatment of malaria, the recent wide spread resistance of Plasmodium falciparum to the currently available anti-malarial drugs like chloroquine and ACT; the resistance of the mosquito vectors to the current conventional insecticides; the serious setback in the development of malaria vaccines and the rampant adverse reactions of some conventional anti-malarial drugs poses some challenges to the breakthrough. Therefore, the plant kingdom provides a better prospect in the search of lead compounds and new drugs with sensitivity against resistant Plasmodium falciparum so as to treat this debilitating parasitic disease in line with the long standing tradition of using phytomedicines in the treatment of malaria. In addition, quinine isolated from Cinchona ledgeria and quinghaosu from Artemisia annua L. for instance, showcases the potential value of herbal medicines in the development of antimalarial drugs (Klayman, 1985). Another species of Plasmodium is Plasmodium berghei parasite often used in predicting the treatment outcomes of any suspected antimalaria agent due to its high sensitivity to chloroquine thereby making it an appropriate 
parasite for this study (Peter, 1998; David, 2004). Plasmodium berghei have been used in studying the activity of potential antimalarials in mice (Pedronic, et al., 2006) because it produces diseases similar to those of human plasmodium infection (Kumar et al., 2006; Peter,1998).

Amodiaquine is a mannich base congener of chloroquine with marginally better efficacy (Miroshnikova et al., 2007) and like chloroquine, it belong to the class of 4aminoquinolines. Due to widespread resistance, malaria therapy now consists of combination of two or more drugs that attack different biochemical processes in the Plasmodium species. Nevertheless, members of this class, like chloroquine at low concentrations stabilizes erythrocyte biomembranes but have specific reactions with the parasite membranes thereby preventing intra-erythrocytic asexual parasites from destroying up to $75 \%$ of host cell haemoglobin (Wellems, 1991).

Nauclea latifolia is one of the plants frequently used in the treatment of malaria by herbal practitioners (Benoit-Vical, 1998). Zirihi et al., (2005) reported that out of thirty three plants, commonly used in west tropical Africa by traditional healers for the treatment of malaria, Nauclea latifolia showed a good anti-plasmodial activity and a weak toxicity. This rubiaceae is a struggling shrub or small tree of about $20 \mathrm{ft}$ high, in savannah woodland or a larger tree of over $100-\mathrm{ft}$ in closed forest. It has been known to have medicinal properties and is commonly used in the treatment of malaria, diabetes, and hypertension and also as laxative (Asanga et al., 2017; Gidado et al., 2005; Asanga et al., 2013; Akpanabiatu et al., 2005). Moreover, Asanga et al., (2017) had reported the antiplasmodial potential of the ethanol extract and fractions of the root of this plant. Since malaria infection often affect the chemistry, physiology and metabolic activities of the erythrocytes and other blood cells in the host body system This research was designed to investigate the effect of the plant extract and fractions on the haematological parameters (red cell, white cell or platelet indices) in Plasmodium berghei infected mice in other to establish if the recommendation of this plant for the treatment of malaria will positively or negatively affect the individuals blood chemistry after oral administration for a period of 5 days. Malaria is a multi-system disease caused by Plasmodium falciparum and other plasmodia species. It virtually affects all parts of the host body due to the parasites ability to move in the blood and permeates most organs in the host. The signs and symptoms of malaria illness results from the invasion of red blood cells by asexual forms of the malaria parasite leading to immunological response by the white blood cells and platelets hence, the resultant biochemical and physiological modifications of the host haematological parameters. However, the high prevalence of malaria in Nigeria, worsened by the reported resistance of the parasite to conventional chemotherapy as well as the quest by scientist to explore, research in some African medicinal plants like Nauclea latifolia in other to validate their antiplasmodial claims warranted this research to investigate whether the reported high therapeutic index for Nauclea latifolia extract and fractions against Plasmodium berghei could have positive or negative effect on the haematological profile of Plasmodium berghei infected mice.

\section{Materials and Methods}

\section{Collection and identification of plant sample, extraction and fractionation}

The roots of Nauclea latifolia were collected from a bush in Ikot Andem Ididep, Ibiono Ibom Local Government Area, Akwa Ibom 
State, Nigeria in August 2015. The root was identified and authenticated by Mr. Etefia of the Department of Pharmacognosy and Natural medicine, University of Uyo, Nigeria. A voucher specimen with herbarium number UUH67G was deposited in the same Department. The root was carefully selected, washed, cut and dried under ambient conditions in the laboratory for days to reduce moisture content and prevent enzyme action. The dried roots were pulverized using mortar and pestle into moderately coarse particles, stored in an air-tight container to prevent photolysis.

About $4.741 \mathrm{~kg}$ of the coarse root sample was introduced into two transparent airtight glass containers and extracted with 12.5 litres of $70 \%$ ethanol by cold maceration. The extract was allowed to stand for 72 hours with ocassional shaking, and then filtered and washed in a step-wise fashion with ethanol until the colour of the filtrate became faint green. The ethanol extract was concentrated using a rotary evaporator at $40^{\circ} \mathrm{C}$. The concentrated ethanol whole extract $127.8 \mathrm{~g}$ (2.7\%) was divided into two. About 19.6g was preserved in a desicator and named the ethanol whole extract. The remaining $108.2 \mathrm{~g}$ was dissolved in $200 \mathrm{ml}$ distilled water and successively partitioned in dichloromethane $(19 \times 250 \mathrm{ml})$, ethyl acetate $(25 \times 250 \mathrm{ml})$, butanol $(40 \times 250 \mathrm{ml})$ and distilled water using separating funnel. Evaporation of the solvents yielded $15.3 \mathrm{~g} \quad(14.14 \%)$ of dichloromethane fraction, $8.3 \mathrm{~g}(7.7 \%)$ of ethyl acetate fraction, $33.7 \mathrm{~g}(31.2 \%)$ of butanol fraction, and $6.5 \mathrm{~g}(6 \%)$ aqueous fraction. These fractions were stored in a dessicator to further concentrate.

\section{Animals}

Forty (40) Swiss albino mice of both sexes, weighing between 14 - 23 g obtained from Animal House, Department of Pharmacology and Toxicology, Faculty of Pharmacy, University of Uyo, Nigeria were used as experimental animal model in the study. The NIH guide for the care and use of laboratory animals (NIH Publication No. 80-23; revised 1978) was observed. The experimental protocol was approved by the Animal ethics committee of the Faculty of Pharmacy University of Uyo, Nigeria. They were given free access to food (standard pellet diet), water and were kept under a 12 hour light/dark cycle at ambient laboratory conditions.

\section{Parasites}

Samples of chloroquine sensitive Plasmodium berghei (NK-65) obtained from National Institute of Medical Research (NIMR), Lagos, Nigeria, maintained by sub-passage were used for the research to evaluate the effect of the plant ethanol extract and fractions on haematological parameters of Plasmodium berghei infected mice used in the study.

\section{Inoculum preparation}

A stock of parasitized erythrocytes was obtained from infected mice, with a minimum peripheral parasitemia of $20 \%$ by cardiac puncture in heparin-coated tube. The percentage parasitaemia was determined by counting the number of parasitized red blood cells against the total number red blood cells. The cell concentration of the stock was determined and diluted with physiological saline such that $0.2 \mathrm{~mL}$ of the final inoculum contained $1 \times 10^{7}$ parasitized red blood cells which are the standard inoculums for the infection of a single mouse (Okokon et al., 2012).

\section{Drugs}

Tablets of artesunate $50 \mathrm{mg}$ (from Mekophar Chemical Pharmaceutical Joint -stock 
Company, Ho Chi Minh City- Vietnam.) were dissolved in $100 \mathrm{ml}$ of distilled water and administered at a dose of $5 \mathrm{mg} / \mathrm{kg}$ body weight of mice as well as amodiaquine 200 mg (from Pfizer Afrique de 1' Ouest Dakar R. P. Senegal) dissolved in $100 \mathrm{ml}$ of distilled water and administered at a dose of $30 \mathrm{mg} / \mathrm{kg}$ body weight of mice were used as positive control to evaluate the effect of ethanol extract and fractions of Nauclea latifolia roots on the haematological indices of Plasmodium berghei infected mice.

Evaluation of the effect of the plant extract/fractions on the haematological indices of already established Plasmodium berghei infected mice

To evaluate the effect of the ethanol extract and fractions on the haematological indices of Plasmodium berghei infected mice during established infection, forty mice were inoculated intraperitoneally with standard inoculum of $1 \times 10^{7}$ Plasmodium berghei parasitized red blood cell. After 72 hours, the mice were randomized into 8 groups of five animals each. Mice in group 1 received distilled water $(10 \mathrm{ml} / \mathrm{kg})$ body weight of mice and served as the negative control group. Groups 2 and 3 (positive control groups) received amodiaquine $(30 \mathrm{mg} / \mathrm{kg} / \mathrm{day}$ body weight) and artesunate $(5 \mathrm{mg} / \mathrm{kg})$ body weight of mice. Moreover, group 4 was administered with ethanol whole extract at a dose of $150 \mathrm{mg} / \mathrm{kg}$ body weight of mice, while groups $5,6,7$, and 8 were administered with dichloromethane, ethyl acetate, butanol and aqueous fractions each at $150 \mathrm{mg} / \mathrm{kg}$ body weight of mice respectively. The drugs, extract and fractions were orally administered to the animals once daily for a period of 5 days.

\section{Blood sampling}

All the mice from each treatment group on the $6^{\text {th }}$ day after treatment were anaesthesized under chloroform, sacrificed and about $1 \mathrm{ml}$ of blood obtained from each mouse through cardiac puncture into tubes already coated with EDTA were used for hematological analysis using automated hematology analyser sysmex KX21, (SYSMEX, Corporation, Japan) (Asanga et al., 2013).

\section{Statistical analysis}

The data were analysed by using GraphPad Prism version 7.0 (GraphPad Software, Inc. San Diego, CA, USA) and the results expressed as Mean + SEM. The significant differences between and within the groups were analysed statistically by One-way ANOVA followed by multiple comparisons of their means using Turkey's post hoc test. Differences were considered statistically significant at $\mathrm{P}<0.05$.

\section{Results and Discussion}

Evaluation of haematological abuses or its implications in animal models and humans are often carried out by evaluating the complete blood count or full counts in order to ascertain changes in erythrocytes, leucocytes and platelets which guide in the diagnosis of anemia, leucocytosis and thrombocytopenia often implicated in malaria infections. Anemia is observed to be one of the basic symptoms of malaria. It is normally evaluated by testing for RBC, PCV or HCT, HGB, MCV, MCH, MCHC, RDW levels and comparing the results with standard values. The marked decrease $(\mathrm{P}<0.05)$ of these parameters (Table 1) in the negative control group was consistent with the results reported by Cyril-Olutayo et al., (2013). The significant decrease $(\mathrm{P}<0.05)$ in $\mathrm{RBC}$ count in the groups treated with artesunate, ethanol extract, dichloromethane, butanol and aqueous fractions when compared with amodiaquine treated group, as well as the marked significant increase $(\mathrm{P}<0.05)$ in $\mathrm{RBC}$ counts of the groups treated with amodiaquine 
when compared with the negative control group suggests that the drug enhanced erythropoietic activities in mice. This further suggests that amodiaquine was more effective than the extract and fractions of Nauclea latifolia roots. It has been established that the normal range of RBC in healthy mice is 9.23 $9.42 \times 10^{6} / \mathrm{mm}^{3}$ (Schnell et al., 2002). Amodiaquine and ethyl acetate fraction, significantly $(\mathrm{p}<0.05)$ increased $\mathrm{RBC}$ counts close to this reference range when compared with the negative control group. The ethyl acetate fraction gave the best haematological results when compared with whole ethanolic extract and extract fractions of the test plant. However, the decreases in the RBC counts in all the treatment groups may be due to nonimmune destruction of parasitized red blood cells.

Hemoglobin (HGB) is an intracellular protein found in the red blood cell and its value often decreases in malaria patients due to the fact that growing parasites do consume haemoglobin (Gravigan et al., 2001). The normal range of HGB in mice is 13.6 - 13.9 $\mathrm{g} / \mathrm{dL}$ (Schnell et al., 2002). The results (Table 1) showed that amodiaquine and ethyl acetate fraction significantly increased $(\mathrm{P}<0.05)$ HGB level whereas other treatment groups insignificantly increased $(\mathrm{P}>0.05) \mathrm{HGB}$ level with the highest effect exhibited by ethyl acetate fraction when compared with the negative control group. Nevertheless, the insignificant increases $(\mathrm{P}>0.05)$ in HGB level from the extract and fractions may be due to the low median dose of $150 \mathrm{mg} / \mathrm{kg}$ body weight of mice. Thus further studies may require increasing the dosage of the extract and fractions of Nauclea latifolia roots, and this is expected to give a significantly more positive results.

Anemia is often classified based on the size of the red blood cells as normocytic (normal $\mathrm{MCV}$ ), macrocytic (increased MCV) or microcytic (decreased MCV) by Bessman et al., (1983). The result of this study showed significant increase $(\mathrm{P}<0.05)$ in MCV was observed in groups of mice treated with dichloromethane fraction when compared with both negative control and amodiaquine groups respectively. However, insignificant changes $(\mathrm{P}>0.05)$ in MCV were observed in all other treatment groups when compared with the negative control group. This result was consistent with that earlier reported by Momoh et al., (2014). The normal range of MCV in healthy mice is $48.9-50 \mathrm{U}^{3}$ (Schnell et al., 2002) so, the increased MCV from the group treated with dichloromethane fraction is a pointer to a possible macrocytic anemia inferred from the study. However, when the values of $\mathrm{HGB}, \mathrm{RBC}$ and $\mathrm{MCV}$ are affected, $\mathrm{MCH}$ and $\mathrm{MCHC}$ are also affected because they are calculated and not measured directly. The result (Table 1) showed that there was significant increase $(\mathrm{P}<0.05)$ in $\mathrm{MCH}$ level in the treatment group of dichloromethane fraction when compared with the negative control group. Also, significant increase $(\mathrm{P}<$ 0.05 ) in MCHC level was noted in amodiaquine when compared with the negative control group. Moreover, significant decreases $(\mathrm{P}<0.05)$ in $\mathrm{MCHC}$ level was noted in the treatment groups when compared with amodiaquine.

Furthermore, indicators of inflammation and infections like WBC increased whereas lymphocytes, neutrophils etc. decreased in the negative control group when compared with the optimal ranges for $\mathrm{WBC}$ and lymphocytes in adult mice as $2.8-5.4 \times 10^{9} / \mathrm{L}$ and 84 $87 \%$ respectively (Schnell et al., 2002). Amodiaquine treatment group significantly decreased in their WBC count but increased in lymphocytes counts when compared with the negative control group. The earlier result was consistent with that reported by some researchers on other plants (Cyril-Olutayo et al., 2013; Momoh et al., 2014) (Table 2). 
Table.1 Effect of the treatment on the red blood cell indices of Plasmodium berghei infected mice

\begin{tabular}{|c|c|c|c|c|c|c|c|c|c|}
\hline S/No. & $\begin{array}{l}\text { TREATMENT } \\
\text { GROUPS }\end{array}$ & $\begin{array}{l}\text { RBC X } \\
10^{6}(\mu \mathrm{L})\end{array}$ & HGB (g/dL) & $\begin{array}{l}\text { MCV } \\
\text { (fL) }\end{array}$ & $\begin{array}{l}\text { MCH } \\
\text { (pg) }\end{array}$ & $\begin{array}{l}\text { MCHC } \\
\text { (g/dL) }\end{array}$ & HCT (\%) & $\begin{array}{l}\text { RDW-SD } \\
\text { (fL) }\end{array}$ & $\begin{array}{l}\text { RDW-CV } \\
(\%)\end{array}$ \\
\hline 1 & $\begin{array}{l}\text { Negative control } \\
\text { (distilled water) }\end{array}$ & $\begin{array}{l}3.69 \pm \\
0.37\end{array}$ & $6.00 \pm 0.58$ & $\begin{array}{l}61.83 \pm 3 \\
00\end{array}$ & $\begin{array}{l}16.30 \pm \\
0.31\end{array}$ & $\begin{array}{l}26.43 \pm \\
0.77\end{array}$ & $\begin{array}{l}22.70 \pm 2.1 \\
1\end{array}$ & $\begin{array}{l}29.60 \pm 1.2 \\
1\end{array}$ & $13.10 \pm 1.23$ \\
\hline 2 & $\begin{array}{l}\text { Amodiaquine } \\
(30 \mathrm{mg} / \mathrm{kg})\end{array}$ & $\begin{array}{l}6.09 \pm \\
1.38 \mathrm{a} * *\end{array}$ & $\begin{array}{l}10.1 \pm 2.00 \\
a^{* *}\end{array}$ & $\begin{array}{l}58.10 \pm 3 \\
00\end{array}$ & $\begin{array}{l}16.70 \pm \\
0.50\end{array}$ & $\begin{array}{l}28.75 \pm \\
0.65 \mathrm{a}^{* *}\end{array}$ & $\begin{array}{l}34.95 \pm 6.1 \\
5 \mathrm{a}^{* *}\end{array}$ & $\begin{array}{l}33.90 \pm 5.5 \\
0\end{array}$ & $15.70 \pm 3.30$ \\
\hline 3 & $\begin{array}{l}\text { Artesunate } \\
(5 \mathrm{mg} / \mathrm{kg})\end{array}$ & $\begin{array}{l}4.04 \pm \\
0.68 \mathrm{~b}^{*}\end{array}$ & $6.55 \pm 0.95 b^{*}$ & $\begin{array}{l}64.50 \pm 6 . \\
90\end{array}$ & $\begin{array}{l}16.30 \pm \\
0.40\end{array}$ & $\begin{array}{l}25.45 \pm \\
2.15 b^{*}\end{array}$ & $\begin{array}{l}25.60 \pm 1.6 \\
0\end{array}$ & $\begin{array}{l}32.20 \pm 2.2 \\
0\end{array}$ & $21.00 \pm 3.00$ \\
\hline 4 & $\begin{array}{l}\text { Ethanol extract }(150 \\
\mathrm{mg} / \mathrm{kg})\end{array}$ & $\begin{array}{l}4.04 \pm \\
0.30 \mathrm{~b}^{*}\end{array}$ & $6.25 \pm 0.55 b^{*}$ & $\begin{array}{l}59.0 \pm \\
0.40\end{array}$ & $\begin{array}{l}15.45 \pm \\
0.25\end{array}$ & $\begin{array}{l}26.20 \pm \\
0.20 b^{*}\end{array}$ & $\begin{array}{l}23.85 \pm 1.9 \\
5 \mathrm{~b}^{*}\end{array}$ & $\begin{array}{l}27.85 \pm 0.4 \\
5 b^{*}\end{array}$ & $11.25 \pm 0.75$ \\
\hline 5 & $\begin{array}{l}\text { Dichloromethane } \\
\text { fraction } \\
(150 \mathrm{mg} / \mathrm{kg})\end{array}$ & $\begin{array}{l}2.27 \pm \\
1.17 \mathrm{~b}^{*}\end{array}$ & $3.85 \pm 1.75 b^{*} c^{*}$ & $\begin{array}{l}73.30 \pm 6 \\
70 \\
\mathrm{~b} * \mathrm{a} * *\end{array}$ & $\begin{array}{l}17.70 \pm \\
1.40 \\
a^{* *}\end{array}$ & $\begin{array}{l}24.20 \pm \\
0.30 a^{*} \\
b^{*}\end{array}$ & $\begin{array}{l}15.85 \pm 7.0 \\
5 \mathrm{~b}^{*} \\
\mathrm{c}^{*}\end{array}$ & $\begin{array}{l}35.85 \pm 0.0 \\
5 \mathrm{a}^{* *}\end{array}$ & $\begin{array}{l}32.25 \pm 15.45 \\
a^{* *}, b^{* *}\end{array}$ \\
\hline 6 & $\begin{array}{l}\text { Ethyl acetate fraction } \\
(150 \mathrm{mg} / \mathrm{kg})\end{array}$ & $\begin{array}{l}4.36 \pm \\
0.10\end{array}$ & $6.85 \pm 0.05 b^{*}$ & $\begin{array}{l}59.75 \pm 1 . \\
25\end{array}$ & $\begin{array}{l}15.75 \pm \\
0.25\end{array}$ & $\begin{array}{l}26.30 \pm \\
0.10 b^{*}\end{array}$ & $\begin{array}{l}26.05 \pm 0.0 \\
5\end{array}$ & $\begin{array}{l}28.15 \pm 0.3 \\
5\end{array}$ & $11.15 \pm 0.75$ \\
\hline 7 & $\begin{array}{l}\text { Butanol fraction } \\
(150 \mathrm{mg} / \mathrm{kg})\end{array}$ & $\begin{array}{l}3.89 \pm \\
0.08 \mathrm{~b}^{*}\end{array}$ & $6.25 \pm 0.05 b^{*}$ & $\begin{array}{l}62.50 \pm 1 \\
50\end{array}$ & $\begin{array}{l}16.10 \pm \\
0.20\end{array}$ & $\begin{array}{l}25.70 \pm \\
0.30 b^{*}\end{array}$ & $\begin{array}{l}24.30 \pm 0.1 \\
0 b^{*}\end{array}$ & $\begin{array}{l}28.20 \pm 0.2 \\
0\end{array}$ & $11.80 \pm 0.10$ \\
\hline 8 & $\begin{array}{l}\text { Aqueous fraction } \\
(150 \mathrm{mg} / \mathrm{kg})\end{array}$ & $\begin{array}{l}3.08 \pm \\
0.17 b^{*}\end{array}$ & $4.85 \pm 0.25 b^{*}$ & $\begin{array}{l}65.00 \pm 0 . \\
10\end{array}$ & $\begin{array}{l}15.75 \pm \\
0.05\end{array}$ & $\begin{array}{l}24.25 \pm \\
0.05 b^{*}\end{array}$ & $\begin{array}{l}20.00 \pm 1.1 \\
0 \mathrm{~b}^{*}\end{array}$ & $\begin{array}{l}31.70 \pm 1.0 \\
0\end{array}$ & $14.95 \pm 1.25$ \\
\hline
\end{tabular}

$\mathrm{a}^{* *}=$ significant increase at $\mathrm{P}<0.05, \mathrm{n}=5$ when compared with negative control group.

$\mathrm{b}^{*}=$ significant decrease at $\mathrm{P}<0.05, \mathrm{n}=5$ when compared with the amodiaquine group.

$\mathrm{c}^{*}=$ significant decrease at $\mathrm{P}<0.05, \mathrm{n}=5$ when compared with the artesunate group.

Table.2 Effect of the treatment on the white blood cell indices of

Plasmodium berghei infected mice

\begin{tabular}{|c|c|c|c|c|c|c|c|}
\hline $\begin{array}{l}\text { TREATMENT } \\
\text { GROUPS }\end{array}$ & $\begin{array}{ll}\text { WBC } & X \\
10^{3}(\mu L) & \end{array}$ & $\begin{array}{l}\text { LYM } \quad X \\
10^{3}(\mu L)\end{array}$ & LYM (\%) & NEUT (\%) & $\begin{array}{l}\text { MONO } \\
(\%)\end{array}$ & $\begin{array}{l}\text { EOSIN } \\
(\%)\end{array}$ & BASO (\%) \\
\hline $\begin{array}{l}\text { Negative control } \\
\text { (distilled water) }\end{array}$ & $10.80 \pm 0.38$ & $6.70 \pm 0.40$ & $67.03 \pm 2.54$ & $26.97 \pm 4.52$ & $1.67 \pm 0.67$ & $4.0 \pm 1.00$ & $0.33 \pm 0.33$ \\
\hline $\begin{array}{l}\text { Amodiaquine }(30 \\
\mathrm{mg} / \mathrm{kg})\end{array}$ & $4.30 \pm 1.80 \mathrm{a}^{*}$ & $\begin{array}{l}2.95 \pm 0.95 \\
a^{*}\end{array}$ & $72.65 \pm 7.95$ & $21.35 \pm 5.95$ & $2.00 \pm 1.00$ & $4.00 \pm 1.00$ & - \\
\hline $\begin{array}{l}\text { Artesunate } \\
(5 \mathrm{mg} / \mathrm{kg})\end{array}$ & $\begin{array}{l}16.95 \pm 1.65 \\
a^{* *}, b^{* *}\end{array}$ & $\begin{array}{l}8.4 \pm 0.60 \\
b^{* *}\end{array}$ & $64.70 \pm 13.50$ & $32.80 \pm 14.00$ & $0.50 \pm 0.71$ & $2.00 \pm 1.00$ & - \\
\hline $\begin{array}{l}\text { Ethanol extract } \\
(150 \mathrm{mg} / \mathrm{kg})\end{array}$ & $8.45 \pm 0.75 \mathrm{c}^{*}$ & $\begin{array}{l}5.95 \pm 0.55 \\
b^{* *} c^{*}\end{array}$ & $71.45 \pm 12.55$ & $24.55 \pm 12.55$ & $1.50 \pm 0.50$ & $2.50 \pm 0.50$ & - \\
\hline $\begin{array}{l}\text { Dichloromethane } \\
\text { fraction } \\
(150 \mathrm{mg} / \mathrm{kg})\end{array}$ & $\begin{array}{l}11.90 \pm 2.30 \\
b^{* *}\end{array}$ & $\begin{array}{l}5.65 \pm 0.05 \\
b^{* *}, c^{*}\end{array}$ & $66.30 \pm 7.70$ & $30.20 \pm 8.20$ & $1.50 \pm 0.50$ & $2.50 \pm 0.50$ & - \\
\hline $\begin{array}{l}\text { Ethyl acetate } \\
\text { fraction } \\
(150 \mathrm{mg} / \mathrm{kg})\end{array}$ & $\begin{array}{ll}9.50 \pm & 2.50 \\
c^{*} & \end{array}$ & $\begin{array}{l}8.65 \pm 0.05 \\
b^{* *}\end{array}$ & $70.45 \pm 2.45$ & $25.05 \pm 1.95$ & $1.50 \pm 0.50$ & $3.50 \pm 0.50$ & $0.50 \pm 0.50$ \\
\hline $\begin{array}{l}\text { Butanol fraction } \\
(150 \mathrm{mg} / \mathrm{kg})\end{array}$ & $\begin{array}{l}10.00 \pm 1.80 \\
b^{* *}, c^{*}\end{array}$ & $\begin{array}{l}4.90 \pm 0.80 \\
c^{*}\end{array}$ & $48.90 \pm 1.00 \mathrm{~b}^{*}$ & $\begin{array}{l}45.10 \pm 2.00 \\
b^{* * *}\end{array}$ & $1.50 \pm 0.50$ & $4.00 \pm 2.00$ & $0.50 \pm 0.50$ \\
\hline $\begin{array}{l}\text { Aqueous fraction } \\
(150 \mathrm{mg} / \mathrm{kg})\end{array}$ & $\begin{array}{l}15.65 \pm 4.05 \\
b^{* *}\end{array}$ & $\begin{array}{l}7.00 \pm 1.60 \\
b^{* *}\end{array}$ & $\begin{array}{l}45.25 \pm 1.55 \\
a^{*}, b^{*}\end{array}$ & $\begin{array}{l}46.28 \pm 2.05 \\
b^{* *}\end{array}$ & $2.50 \pm 0.50$ & $\begin{array}{l}6.00 \pm 1.00 \\
c^{* *}\end{array}$ & $1.00 \pm 0.00$ \\
\hline
\end{tabular}

$\mathrm{a}^{*}=$ significant decrease at $\mathrm{P}<0.05, \mathrm{n}=5$ when compared with the negative control group.

$\mathrm{a}^{* *}=$ significant increase at $\mathrm{P}<0.05, \mathrm{n}=5$ when compared with negative control group.

$\mathrm{b}^{*}=$ significant decrease at $\mathrm{P}<0.05, \mathrm{n}=5$ when compared with the amodiaquine group.

$\mathrm{b}^{* *}=$ significant increase at $\mathrm{P}<0.05, \mathrm{n}=5$ when compared with the amodiaquine group.

$\mathrm{c}^{*}=$ significant decrease at $\mathrm{P}<0.05, \mathrm{n}=5$ when compared with the artesunate group.

$\mathrm{c}^{* *}=$ significant increase at $\mathrm{P}<0.05, \mathrm{n}=5$ when compared with the artesunate group. 
Table.3 Effect of the treatment on platelet indices of plasmodium berghei infected mice

\begin{tabular}{|l|l|l|l|l|}
\hline $\begin{array}{l}\text { TREATMENT } \\
\text { GROUPS }\end{array}$ & PLT X 10 ${ }^{3}(\mu \mathbf{L})$ & PDW (fL) & MPV (fL) & P-LCR (\%) \\
\hline $\begin{array}{l}\text { Negative control } \\
\text { (distilled water) }\end{array}$ & $205.7 \pm 62.30$ & $14.43 \pm 0.33$ & $9.03 \pm 0.17$ & $22.10 \pm 0.87$ \\
\hline $\begin{array}{l}\text { Amodiaquine } \\
\text { mg/kg) }\end{array}$ & $930.50 \pm 310.50 \mathrm{a}^{* *}$ & $8.05 \pm 0.95 \mathrm{a}^{*}$ & $6.85 \pm 0.45 \mathrm{a}^{*}$ & $6.80 \pm 2.50 \mathrm{a}^{*}$ \\
\hline $\begin{array}{l}\text { Artesunate } \\
(5 \mathrm{mg} / \mathrm{kg})\end{array}$ & $692.0 \pm 257.00$ & $10.70 \pm 1.40$ & $8.60 \pm 0.60 \mathrm{~b}^{* *}$ & $17.70 \pm 3.70 \mathrm{~b}^{* *}$ \\
\hline $\begin{array}{l}\text { Ethanol extract }(150 \\
\text { mg/kg) }\end{array}$ & $221.00 \pm 36.00 \mathrm{~b}^{*}$ & $14.25 \pm 2.45 \mathrm{~b}^{* *}$ & $9.50 \pm 0.20 \mathrm{~b}^{* *}$ & $23.95 \pm 2.75 \mathrm{~b}^{* *}$ \\
\hline $\begin{array}{l}\text { Dichloromethane } \\
\text { fraction }(150 \mathrm{mg} / \mathrm{kg})\end{array}$ & $748.50 \pm 404.50 \mathrm{a}^{* *}$ & $12.10 \pm 3.10$ & $8.60 \pm 1.10 \mathrm{~b}^{* *}$ & $19.50 \pm 7.70 \mathrm{~b}^{* *}$ \\
\hline $\begin{array}{l}\text { thylacetate fraction } \\
(150 \mathrm{mg} / \mathrm{kg})\end{array}$ & $176.50 \pm 39.50 \mathrm{~b}^{*}$ & $11.75 \pm 0.25$ & $8.80 \pm 0.40 \mathrm{~b}^{* *}$ & $18.75 \pm 3.05 \mathrm{~b}^{* *}$ \\
\hline $\begin{array}{l}\text { Butanol fraction } \\
(150 \mathrm{mg} / \mathrm{kg})\end{array}$ & $183.50 \pm 70.50 \mathrm{~b}^{*}$ & $13.85 \pm 1.75 \mathrm{~b}^{* *}$ & $9.25 \pm 0.15 \mathrm{~b}^{* *}$ & $21.75 \pm 1.75 \mathrm{~b}^{* *}$ \\
\hline $\begin{array}{l}\text { Aqueous fraction } \\
(150 \mathrm{mg} / \mathrm{kg})\end{array}$ & $224.50 \pm 49.50 \mathrm{~b}^{*}$ & $10.10 \pm 1.10 \mathrm{a}^{*}$ & - \\
\hline
\end{tabular}

Nevertheless, treatment groups of artesunate, dichloromethane, butanol, and aqueous fractions significantly decreased in their WBC counts when compared with that of amodiaquine. In a general note, the observed lymphocytopenia in all the treatment groups may be due to antibody production after the initiation of antiplasmodial treatment in the acute malaria, the results was consistent with earlier report on another plant (Okoroiwu et al., 2014).

Platelets act as acute phase reactant to infection or inflammation. The results (Table 3) of the analysis showed that there were significant increases in the PLT counts in the groups administered with amodiaquine as well as dichloromethane fraction of Nauclea latifolia root when compared with the negative control group suggesting their possible role as acute phase reactant to infection induced by Plasmodium berghei in mice. However, significant decreases in PLT counts were observed in the treatment groups of ethanol extract, (ethyl acetate, butanol and aqueous) fractions when compared with amodiaquine treatment group. Therefore, the low PLT counts observed in this study when compared with the healthy adult mice 8.9 $12.3 \times 10^{5} / \mathrm{mm}^{3}$ (Schnell et al., 2002) was due to malaria and the report was consistent with those earlier reported by some researchers (Taha et al., 2007; Odaibo and Igbeneghu, 2013). Moreover, the thrombocytopenia may be due to the destruction as immune complexes generated by malaria antigen could led to sequestration of injured platelets by macrophages in the spleen and platelet consumption in disseminated intravascular coagulation together with platelet dysfunction resulting in hyper aggregation (Erhart et al., 2004). However, amodiaquine and dichloromethane fraction treatment groups significantly increased in their PLT counts when compared with the negative control group,

MPV reveals the average size of platelets as well as being significant when investigating the ability of a drug to enhance blood clotting. 
The results (Table 3) showed that there was significant reduction in MPV levels of amodiaquine treatment group when compared with that of the negative control group. This result was consistent with the report by Yakubu et al., (2007) on another plant but inconsistent with that reported by Momoh et al., (2014) on Alstonia boonie extract. Nevertheless, all the treatment groups significantly increased their MPV levels when compared with the amodiaquine treatment group.

Malaria induction in the mice led to hematological aberrations which resulted in anemia, leucocytosis and thrombocytopenia as observed in all the treatment groups with worst case being reported in the negative control group. However, amodiaquine, ethyl acetate, butanol and aqueous fractions treated groups showed significant performance in enhancing mild erythropoiesis, as well as in protecting blood cells from potential infections resulting from the inflammatory responses by Plasmodium berghei in malaria conditions.

\section{Acknowledgement}

We appreciate the contributions and technical skills of $\mathrm{Mr}$ Aniefiok Ukpong of the Department of Clinical Pharmacology, University of Uyo Teaching Hospital, Uyo, Akwa Ibom State, Nigeria.

\section{Conflict of Interest}

There was no conflict of interest among the authors in presenting this article for publication.

\section{References}

Akpanabiatu MI et al., Rat serum electrolytes, lipid profile and cardiovascular activity on Nauclea latifolia leaf extract administration. Indian $\mathrm{J}$ Clin Biochem 2005; 20(2): 29 - 35.

Asanga EE et al., Hematological parameters of alloxan-induced diabetic rats treated with ethanol extract and fractions of Nauclea latifolia Leaves. Eur Sci J 2013; 9(25): 78 - 84.

Benoit-Vical $\mathrm{F}$ et al., In vitro antiplasmodial activity of stem and root extracts of Nauclea latifolia S.M. (Rubiaceae). J Ethnopharmacol 1998; 61(3): 173 - 8.

Bessman JD et al., Improved classification of anemias by MCV and RDW. Amer $\mathrm{J}$ Clin Pathol 1983; 80: 322 - 6.

Brian M et al., (2008). Malaria; progress, perils and prospects for eradication. $\mathbf{J}$ Clin Sci 2008; 9: 23 - 34.

Cyril- Olutayo, MC et al., Effects of Angeissus leiocarpus on hematological parameters of mice infected with Plasmodium berghei. J Plant Studies 2013; 2(2): 13 - 21.

David AF et al., Antimalarial drug discovery: efficacy models for compound screening. Nature Rev Drug Discov 2004; 3: $509-20$.

Erhart, L. M., Yingyuen, K., Chuanak, N., Buathong, N., Laoboonchai, A., Miller, R. S., Meshnick, S. R., Gasser, R. A. and Wongsrichanalai, C. (2004). Hematological and clinical indices of malaria in a semi-immune population of Western Thailand. American Journal of Tropical Medicine and Hygiene, 70, 8 14.

Fakhreldin, M., Brian, J. and Eleanor, M. (2003). Differential Induction of TGF(Beta) determines the outcome of lethal and non-lethal Plasmodium yoelii infections. Journal of Immunology, 13, $35-45$.

Federal Ministry of Health (2004). Government in action malaria report ( $\mathrm{p}$. 5 - 6). Abuja, Nigeria: Government House Press.

Gidado, A., Ameh D. A. and Atawodi S. E 
(2005). Effect of Nauclea latifolia leaves aqueous extracts in blood glucose levels of normal and alloxaninduced diabetic rats. African Journal of Biotechnology, 4(1), 91 - 93.

Gravigan, C. S., Dalton, S. P. and Bell, A. (2001). The role of aminopeptidases in hemoglobin degradation in Plasmodium falciparum-infected erythrocytes. Molecular Biochemistry and Parasitology, 117(1), $37-48$.

Khan, A. S., Qurshi, F., Shah, A. H. and Malik, S. A. (2002). Spectrum of malaria in Hajj pilgrims. Journal of Ayub Medical College, 14 (4), 23 - 25.

Klayman, D. L. (1985). Science, 228, 1049 1054.

Kumar, K. A., Sign, S., Babu, P. P. (2006). Studies on the glycoprotein modification in erythrocyte Membrane during experimental cerebral malaria. Experimental Parasitology, 114, 173 179.

Miroshnikova, O. V., Hudson, T. H., Gerena, L., Kyle, D. E., Ai, J. and Lin, A. J. (2007). Synthesis and antimalarial activity of new isotebuquine analogues. Journal of Medicinal Chemistry, 50, 889 - 896.

Momoh, J., Longe, A. O. and Campbell, C. A. (2014). In vivo antiplasmodial and In vitro antioxidant activity of ethanolic leaf extract of Alstonia boonie (EWE AHUN) and its effects on some biochemical parameters in Swiss albino mice infected with Plasmodium berghei NK 65. European Scientific Journal, 10 (18), $68-82$.

Odaibo, A. B. and Igbeneghu, C. (2013). Impact of acute malaria on some hematological parammeters in a semiurban community in South-Western Nigeria. Acta Parasitologica Globalis, 4 (1), 1- 5 .

Okokon, J. E., Ettebong, E. O., Udobang, J. A. and Obot, J. (2012). Antiplasmodial and anti-ulcer activities of Melanthera scandens. Asian Pacific Journal of Tropical Biomedicine, 14, 16 - 20.

Okoroiwu, I. L., Obeagu, E. I., Elemchukwu, Q. and Ochei, K. C. (2014). Some hematological parameters in malaria parasitaemia. IOSR Journal of Dental and Medical Sciences, 13 (9), $74-77$.

Olayemi, S. O., Arikawe, A. P., Akinyede, A., Oreagba, A. T. and Awodele, O. (2012). Effect of malarial treatments on biochemical parameters and plasma $\mathrm{pH}$ of mice infected with Plasmodium berghei. International Journal of Pharmacology, 8 (6), 549 - 554.

Ovuakporaye, S. I. (2011). Effect of malaria parasite on some haematological parameters: red blood cell count, packed cell volume and haemoglobin concentration. Journal of Medical and Applied Biosciences, 3, 1 - 7.

Pedroni, H. C., Betton, C. C., Splalding S. M. and Coaster, T. D. (2006). Plasmodium: Development of irreversible experimental malaria model in wistar rats. Experimental Parasitology, 113, 193 - 196.

Peter, I.T. and Anatoli, V. K. (1998). The current global malarial situation: Malaria parasite biology, Pathogenesis and protection. ASM Press W. D. C, London, Pp. 11 - 22.

Rose, M. S. (1971). Epitaph for the MCHC. British Journal of Medicine, 4, 169.

Schnell, M. A., Hardy, C. and Wilson, J. (2002). Effect of blood collection technique in mice on clinical pathology parameters. Human Gene Therapy, 13 (1), $155-162$.

Smyth, J. D. (1994). Animal Parasitology. Cambridge University Press, New York, Pp. 549.

Snow, R.W., Guera, C.A., Noov, A.M., Myint, H.Y and Hays, A. (2005): The global distribution of clinical episodes of Plasmodium falciparium malaria. 
Nature, 434, 214 - 217.

Taha, K., El-Dein, S. D., Idrees, M., Makboul, G. and Baidas, G. (2007). Hematological changes in malaria in relation to Plasmodium species. Kuwait Medical Journal, 39 (3), 262 - 267.

Wellems, T. E. (1991). How chloroquine works? Nature, 355, 108 - 109.

Williams, W. J. (1983). Examination of the blood. In: Williams WJ, Beutler E, Erslev AJ, Lichtman MA, eds. Hematology, 3rd ed. New York: McGraw-Hill, Pp. 9-14.

Wintrobe, M. M. (1981). Principles of hematologic examination. In: Wintrobe
MM, ed. Clinical hematology, 8th ed. Philadelphia: Lea and Febiger, Pp. 7-19.

World Health Organization (WHO) (2008). World Malaria Report by Roll Back Malaria Partnership, New York.

Yakubu, M. T., Akanji, M. A. and Oladiji, A. T. (2007). Hematological evaluation in male albino wistar rats following chronicadministration of aqueous extract of Fadogia agrestis stem. Pharmacological Management, 3, 34 38.

Zirihi, G. N., Mambu, L., Guede-Guina, F., Bodo, B., Grellier, P. (2005). Journal of Ethnopharmacology, 98, 281 - 285.

\section{How to cite this article:}

Asangha, E.E., G.O. Igile, I.A. Iwara, P.E. Ebong and Eseyin, O.A. 2017. Hematological Indices of Plasmodium berghei Infected Mice Treated with Ethanol Extract and Fractions of Nauclea latifolia Roots. Int.J.Curr.Microbiol.App.Sci. 6(12): 2546-2556.

doi: https://doi.org/10.20546/ijcmas.2017.612.295 